\title{
Anti-oxidant activities of kiwi fruit extract on carbon tetrachloride-induced liver injury in mice
}

\author{
Wonyoung Kang, Heekyoung Yang, Hyun Ju Hong, Chang Hoon Han, Young Jae Lee* \\ College of Veterinary Medicine and Veterinary Medical Research Institute, Jeju National University, Jeju 690-756, Korea
}

(Received: February 16, 2012; Revised: November 5, 2012; Accepted: November 27, 2012)

\begin{abstract}
The kiwi (Actinidia deliciosa) is well known to contain anti-oxidants. In this study, we investigated the anti-oxidant effects of kiwi extract on carbon tetrachloride $\left(\mathrm{CCl}_{4}\right)$ induced liver injury in BALB/c mice. The radical scavenging effect of $80 \%$ methanol extract of Halla-Gold kiwi was observed. For the animal study, mice were randomly divided into four groups: normal group, $\mathrm{CCl}_{4}$-induced model group, kiwi extract administered group, and silymarin treated group. The kiwi extract was provided daily for 10 days. At the $24 \mathrm{~h}$ after last administration, $\mathrm{CCl}_{4}$ was injected. The kiwi extract showed strong inhibitory effect of DPPH radicals and superoxide scavenging. In animal study, administration of $\mathrm{CCl}_{4}$ resulted in significantly elevated plasma levels of ALT and AST but they decreased in kiwiextract pretreated group. Anti-oxidant enzymes such as GSH-px and GSH-rd were restored in the kiwi extract treatment group. Histopathological degeneration was also prevented in the kiwi extract treated group compared with of the control group, which exhibited $\mathrm{CCl}_{4}$-induced hepatotoxicity. On the basis of the obtained results, it can be concluded that kiwi extract showed protective effects, not only as anti-oxidant effects, but also in the protection of hepatotoxicity in $\mathrm{CCl}_{4}$-intoxicated mice.
\end{abstract}

Keywords : antioxidant, carbon tetrachloride, cytochrome P450 2E1, hepatotoxicity, kiwi fruit

\section{Introduction}

Liver injury has increased as a result of exposure to higher levels of environmental toxins, as the liver plays an important role in the detoxification of most environmental toxins entering the body [10]. It is well known that the hepatotoxic effect of carbon tetrachloride $\left(\mathrm{CCl}_{4}\right)$ is due to oxidative damage by free radical generation, and the antioxidant properties of hepato-protective drugs are their primary functionalities. Because of the similarity of cirrhotic responses induced by $\mathrm{CCl}_{4}$ in animals, as compared to humans [16, 21, 23], $\mathrm{CCl}_{4}$ is commonly used as a hepatotoxin in experimental studies [13]. Kiwi fruits contain abundant vitamins, polyphenols, and lipophilic constituents, and are used for the treatment of many different types of cancers like stomach, lung and liver cancer $[4,17]$. Several studies have shown that extracts of kiwi fruits inhibit cancer cell growth and exhibit cell protection against oxidative DNA damage in vitro [17]. However, it is not known whether kiwi fruits can prevent or alleviate liver injury induced by $\mathrm{CCl}_{4}$, and the mechanisms by which kiwi fruits may protect against $\mathrm{CCl}_{4}$-induced hepatotoxicity are unclear. In this study, we aimed to investigate the effects of kiwi fruits, especially Halla-Gold kiwi fruit produced in Jeju island in South Korea, on $\mathrm{CCl}_{4}$-induced oxidative stress.

\section{Materials and Methods}

\section{Preparation of the kiwi extract}

Korean kiwifruit (Actinidis chinensis var. "Halla Gold") a new kiwifruit cultivar bred by the Jeju Rural Development Administration. The pulp of the kiwi fruits were extracted in $80 \% \mathrm{MeOH}$ after freeze-drying, and were thereafter referred to as kiwi extract. The kiwi extracts were freeze-dried and were used for in vitro experiments and for animal treatment studies.

\section{In vitro assay of antioxidant activity}

Diphenylpicrylhydrazyl (DPPH) radical scavenging assay: The scavenging activity of kiwi extract was measured using the stable radical DPPH. Briefly, the kiwi extract was added to $0.2 \mathrm{mM}$ DPPH solution $(100 \mu \mathrm{L})$ at various concentrations $(0 \sim 10 \mathrm{mg} / \mathrm{mL})(100 \mu \mathrm{L})$, and was incubated at $37^{\circ} \mathrm{C}$ for $30 \mathrm{~min}$. The absorbance was measured at $490 \mathrm{~nm}$ and vitamin $\mathrm{C}$ and $\mathrm{E}$ were used as reference compounds. The inhibition percentage $(\%)$ of radical scavenging activity was calculated as $\left(1-A_{s} / A_{0}\right) \times 100$, where $\mathrm{A}_{0}$ and $\mathrm{A}_{\mathrm{s}}$ are the absorbance of the control and sample, respectively.

$\mathrm{O}_{2}^{-}$scavenging assay: The $\mathrm{O}_{2}^{-}$scavenging activity was measured by monitoring the $\mathrm{O}_{2}^{-}$induced reduction of

*Corresponding author

Tel: +82-64-702-4217, Fax: +82-64-756-3354

E-mail: yjlee3@jejunu.ac.kr 
nitroblue tetrazolium chloride (NBT) to the blue chromogen diformazan [7]. $\mathrm{O}_{2}^{-}$was generated by the phenazine methosulphate (PMS)/nicotinamide adenine dinucleotide (NADH) system. The reaction mixtures in the sample wells contained the following reagents: $0.5 \mathrm{mM} \mathrm{NBT}(20 \mu \mathrm{L}), 0.5 \mathrm{mM}$ $\mathrm{NADH}(60 \mu \mathrm{L}), 0.1 \mathrm{mM}$ PMS $(20 \mu \mathrm{L})$ and kiwi extract at various concentrations $(0 \sim 10 \mathrm{mg} / \mathrm{mL})(20 \mu \mathrm{L})$. All reagents and kiwi extract were dissolved in $30 \mathrm{mM}$ Tris- $\mathrm{HCl}$, $\mathrm{pH}$ 8.0. After the mixtures were incubated at $37^{\circ} \mathrm{C}$ for $10 \mathrm{~min}$, the absorbance was measured at $560 \mathrm{~nm}$ and was compared with the vitamin E content.

\section{Animals and treatment}

6-week-old, male BALB/c mice were purchased from Orient (Korea). All mice were allowed free access to rodent chow (Charles River, USA) and tap water, maintained in a controlled environment at $22 \pm 2^{\circ} \mathrm{C}$ and $50 \pm 5 \%$ relatively humidity with a $12 \mathrm{~h}$ dark/light cycle, and acclimated for at least 1 week before use. All animal experiments were carried out in accordance with the National Institute of Health's Guide for the Care and Use of Laboratory Animals, and were approved by the Institutional Animal Care and Use Committee of Jeju National University (approval No. 20080010). Halla-Gold $80 \% \mathrm{MeOH}$ extract were prepared in saline, and silymarin (Sigma, USA) was prepared by suspension in 5\% carboxyl methylcellulose as test compound. Mice were randomly divided four groups of 10 . One group of mice was given saline $(0.05 \mathrm{~mL} / 10 \mathrm{~g} /$ day, p.o. $)$ as a control and a second group of mice were given saline $(0.05 \mathrm{~mL} / 10 \mathrm{~g} /$ day, p.o. $)$ as a $\mathrm{CCl}_{4}$ control. The third group of mice received Hallagold $80 \% \mathrm{MeOH}(100 \mathrm{mg} / \mathrm{kg} /$ day, p.o. $)$ and the forth group of mice received silymarin $(100 \mathrm{mg} / \mathrm{kg} /$ day, p.o.). All groups were treated once daily for 10 consecutive days. $24 \mathrm{~h}$ after the final treatment, the first group of the mice were treated with olive oil (Sigma) $(0.1 \mathrm{~mL} / 10 \mathrm{~g}$, i.p.) and the other groups of mice were treated with $\mathrm{CCl}_{4}(20 \mathrm{mg} / \mathrm{kg}$, i.p., dissolved in olive oil). $24 \mathrm{~h}$ after administration of olive oil and $\mathrm{CCl}_{4}$, the mice were sacrificed with $95 \% \mathrm{CO}_{2}$ and $5 \% \mathrm{O}_{2}$ gas, and blood was collected from the caudal vena cava. The cranial lobes of livers were separated and were fixed in $10 \%$ buffered formaldehyde solution. The remainder of the livers were frozen quickly in dry ice and were stored at $-80^{\circ} \mathrm{C}$ for future study.

\section{Measurement of plasma alanine aminotransferase and aspartate aminotransferase}

Plasma alanine amino transferase and aspartate amino transferase were measured by automatic blood analyzer Pronto evolution (BPC, Italy) using commercial reagents (Asan pharm, Korea).

\footnotetext{
Measurement of NOx concentration and antioxidant activity

Analysis of NOx concentration in plasma: The plasma level of NO metabolites (NOx; nitrite and nitrate) was measured with an automated NO analyzer (Eicom, Japan).
}

Briefly, nitrite and nitrate in plasma were separated by a reverse-phase separation column and the nitrate was reduced to nitrite in a reduction column. Nitrite was then mixed with Griess reagents (sulfanilamide and naphthalene-ethylene diamine dihydrochloride), and the absorbance at $540 \mathrm{~nm}$ was measured by a flow-through spectrophotometer.

Assay of glutathione peroxidase activity in RBC: Total glutathione peroxidase (GSH-Px) activity in RBC was assayed using a commercial kit (Cayman chemical, USA). Briefly, assay buffer $(50 \mathrm{mM}$ Tris-HCl, $\mathrm{pH} 7.6$, containing 5 mM EDTA) and a co-substrate mixture containing nicotinamide adenine dinucleotide phosphate (NADPH) were mixed and were added to RBC lysates. The reaction was started by the addition cumene hydroperoxide as quickly as possible, and was monitored by continuous spectrophotometry at 340 $\mathrm{nm}$ and $25^{\circ} \mathrm{C}$.

Assay of glutathione reductase activity in liver: Total glutathione reductase (GSH-Rd) activity in liver was assayed using commercial kit (Cayman chemical, USA). Briefly, after assay buffer $(50 \mathrm{mM}$ potassium phosphate, $\mathrm{pH} 7.5$, containing $1 \mathrm{mM}$ EDTA) and oxidized glutathione (GSSG) were mixed, added to liver homogenates. The reaction was started by the addition NADPH as quickly as possible, and monitored by a continuous spectrophotometry at $340 \mathrm{~nm}$ and $25^{\circ} \mathrm{C}$.

\section{Western blot}

For immunoblotting, liver tissues were homogenized in buffer containing $5 \mathrm{mM}$ Tris- $\mathrm{HCl} \mathrm{pH} \mathrm{7.4,320} \mathrm{mM} \mathrm{sucrose,}$ supplemented with fresh $1 \mathrm{mM}$ phenylmethylsulfonyl fluoride (PMSF).

Liver homogenates were centrifuged at $10,000 \times \mathrm{g}$ for 20 $\min$ at $4^{\circ} \mathrm{C}$, and proteins in supernatants were estimated using the modified Bradford assay [1]. $40 \mu \mathrm{g}$ proteins were resolved using $10 \%(\mathrm{v} / \mathrm{v})$ SDS-PAGE and were transferred onto PVDF membrane (Millipore, USA) for $90 \mathrm{~min}$ at $110 \mathrm{~V}$. They were then incubated in blocking buffer TTBS $(20 \mathrm{mM}$ Tris-HCl pH 7.6, $137 \mathrm{mM} \mathrm{NaCl}, 0.1 \%$ Tween-20) supplemented with $5 \%(\mathrm{w} / \mathrm{v})$ skimmed milk for $90 \mathrm{~min}$, washed in TTBS for $30 \mathrm{~min}$ and incubated with the following antibodies: cytochrome P4502E1 (1:5,000; Abcam, UK), anti-4hydroxylnonenal $(1: 1,000 ;$ R\&D systems, USA) and $\beta$-actin $\left(1: 2,500\right.$; Sigma) diluted in TTBS overnight at $4^{\circ} \mathrm{C}$. Following 50 min washes in TTBS the membranes were incubated with anti-rabbit IgG or anti-mouse IgG HRP-linked secondary antibodies (Santa Cruz Bitotechnology, USA) at 1 : 10,000 or $1: 5,000$ in TTBS for $40 \mathrm{~min}$. Reactive bands were revealed using enhanced chemiluminesence reagents (Intron Biotechnology, USA).

\section{Histological examinations}

Livers were isolated from mice and were fixed in $10 \%$ formaldehyde. The fixed tissues were then embedded in paraffin and were sectioned $(4.0 \mu \mathrm{m})$. The sections were then 
Table 1. Effects of kiwi $80 \% \mathrm{MeOH}$ extract on radical scavenging

\begin{tabular}{lcc}
\hline \hline & $\begin{array}{c}\text { DPPH radical } \mathrm{IC}_{50} \\
(\mathrm{mg} / \mathrm{mL})\end{array}$ & $\begin{array}{c}\text { Superoxideradical } \mathrm{IC}_{50} \\
(\mathrm{mg} / \mathrm{Ml})\end{array}$ \\
\hline Vit C & $0.01 \pm 0.001$ & - \\
Vit E & $0.01 \pm 0.001$ & $0.24 \pm 0.03$ \\
Halla-gold kiwi & $1.91 \pm 0.49^{* * *}$ & $1.86 \pm 0.04^{* * *}$ \\
Zespri & $2.37 \pm 0.39^{* * *}$ & $7.3 \pm 0.8^{* * * \# \#}$ \\
\hline
\end{tabular}

Values are mean $\pm \mathrm{SD} .{ }^{* * *} p<0.001 v s$. VitE, ${ }^{\# \#} p<0.001 v s$. HallaGold kiwi.

stained with hematoxylin and eosin and were examined under light microscope to determine histological changes.

\section{Statistical analysis}

All results are presented as the mean \pm SEM. Comparisons among the results were carried out using LSD tests and one way analysis of variance (ver. 12.0; SPSS, USA). $P$ values $<0.05$ were considered significant.

\section{Results}

\section{Anti-oxidative effects of Halla-Gold kiwi fruit extract}

An investigation of the anti-oxidant effects in vitro demonstrated that Halla-Gold kiwi fruit extract had stronger antioxidant effects compared with green kiwi extract (Table 1).

\section{Effect of Hall-Gold kiwi fruit extract on $\mathrm{CCl}_{4}$-induced hepatotoxicity}

Serum hepatic and lipid biochemical data for the evaluation of $\mathrm{CCl}_{4}$-induced hepatotoxicity are showed in Fig. 1, respectively. There was a significant increase of serum alanine aminotransferase (ALT) and aspartate aminotransferase (AST) activities in the $\mathrm{CCl}_{4}$-treated group, as compared to the control, indicating $\mathrm{CCl}_{4}$-induced damage to the hepatic cells $(p<0.001)$. However, treatment with kiwi extract prior to the $\mathrm{CCl}_{4}$ challenge was observed to reverse the $\mathrm{CCl}_{4}$ induced alteration of ALT and AST $(p<0.001)$. These results suggest that kiwi extract provides protection against $\mathrm{CCl}_{4}$ induced liver injury in mice.

\section{Effect of Hall-Gold kiwi fruit extract on anti-oxidative} enzymes and $\mathrm{NO}_{\mathrm{X}}$ levels in $\mathrm{CCl}_{4}$-induced hepatotoxicity

GSH-px activity in RBC, and plasma NOx concentrations are shown in Figs. 2 and 3. GSH is a non-enzymatic antioxidant in the detoxification pathway, which reduces the toxic metabolites of $\mathrm{CCl}_{4}$. GSH-px activity determined in the $\mathrm{CCl}_{4}$ group was significantly lower $(p<0.01)$ than that in the control. Mice treated with kiwi extract showed significantly increased GSH-px activity $(p<0.05)$. In addition, a high production of NO has been suggested as a cause of tissue injury. Mean $\mathrm{NO}_{\mathrm{X}}$ levels among the groups were not found to differ in this study. The activity of GSH-rd in liver was showed in Fig. 4. GSH-rd activity in the $\mathrm{CCl}_{4}$ group was reduced, but
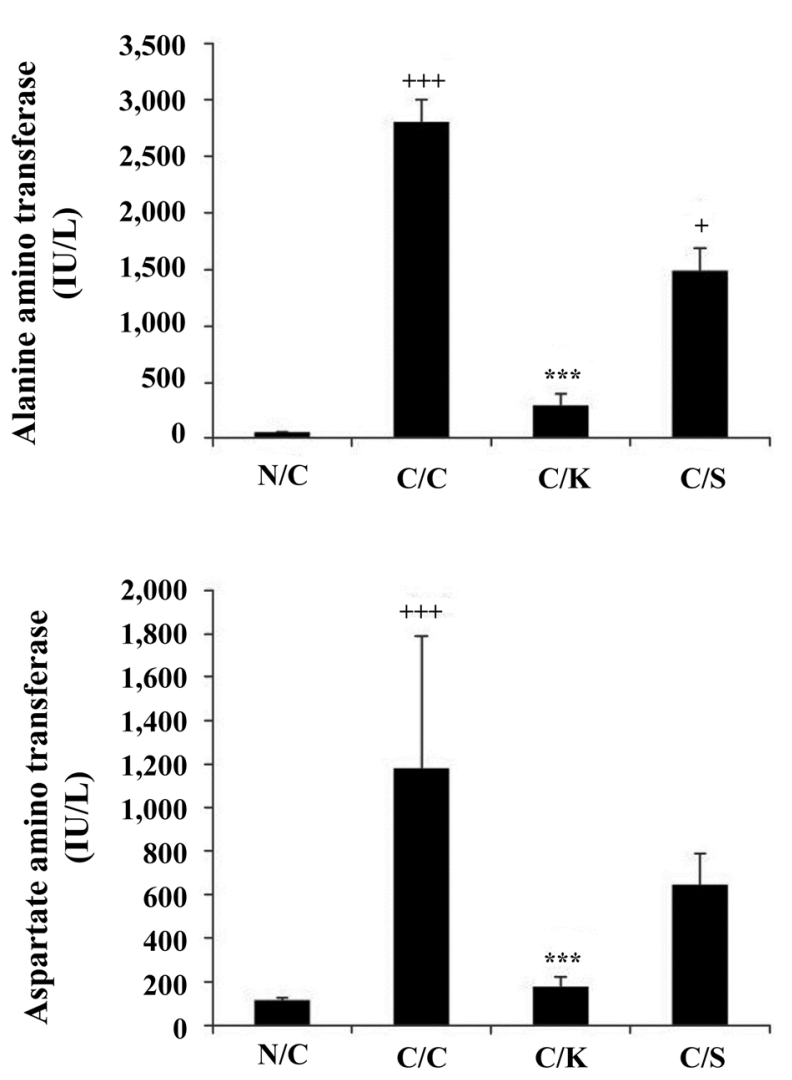

Fig. 1. Plasma alanine aminotransferase (ALT) and aspartate aminotransferase (AST) levels. (A) ALT and (B) AST levels in serum decreased by treatment of kiwi extract. $\mathrm{N} / \mathrm{C}$ : normal mice, $\mathrm{C} / \mathrm{C}$ : $\mathrm{CCl}_{4}$ control, $\mathrm{C} / \mathrm{K}$ : injected with $\mathrm{CCl}_{4}$ after treatment of Halla-Gold kiwi fruits, $\mathrm{C} / \mathrm{S}$ : injected with $\mathrm{CCl}_{4}$ after treatment of silymarin. Values are mean \pm SEM. ${ }^{+} p<0.05,{ }^{+++} p<$ 0.001 vs. $\mathrm{N} / \mathrm{C} ;{ }^{* * *} p<0.001$ vs. C/C.

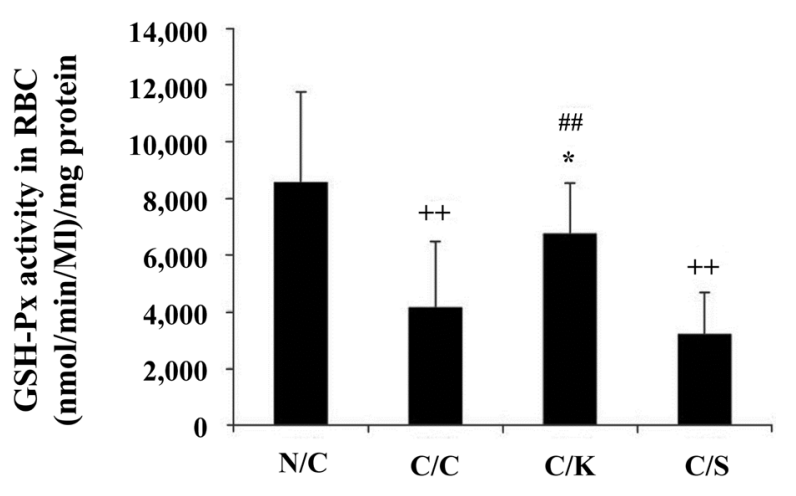

Fig. 2. Glutathione peroxidase activity in $\mathrm{RBC}$. $\mathrm{N} / \mathrm{C}$ : normal mice, $\mathrm{C} / \mathrm{C}$ : $\mathrm{CCl}_{4}$ control, $\mathrm{C} / \mathrm{K}$ : injected with $\mathrm{CCl}_{4}$ after treatment of Halla-Gold kiwi fruits, $\mathrm{C} / \mathrm{S}$ : injected with $\mathrm{CCl}_{4}$ after treatment of silymarin. Values are mean $\pm \mathrm{SEM} .{ }^{++} p<0.01 v s . \mathrm{N} / \mathrm{C}$; ${ }^{*} p<0.05$ vs. C/C; ${ }^{\#} p<0.01$ vs. C/S.

kiwi extract and syrimarin prevented inhibition of enzyme activity. 


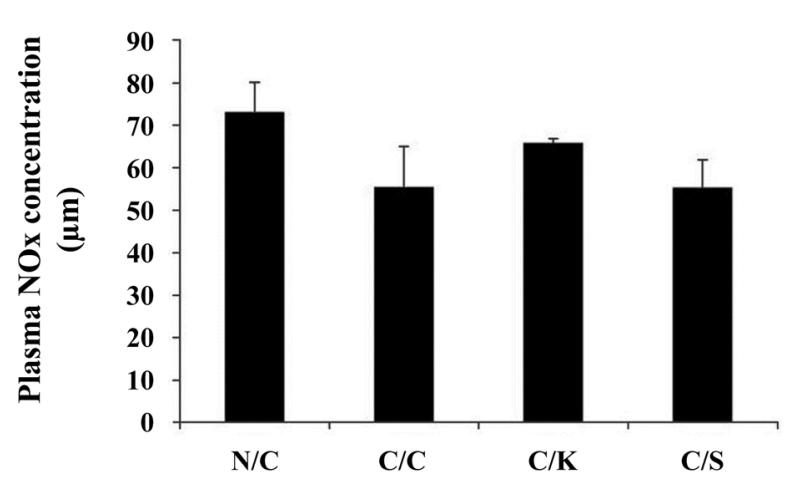

Fig. 3. Plasma nitrite and nitrate $(\mathrm{NOx})$ concentration. $\mathrm{N} / \mathrm{C}$ : normal mice, $\mathrm{C} / \mathrm{C}$ : $\mathrm{CCl}_{4}$ control, $\mathrm{C} / \mathrm{K}$ : injected with $\mathrm{CCl}_{4}$ after treatment of Halla-Gold kiwi fruits, $\mathrm{C} / \mathrm{S}$ : injected with $\mathrm{CCl}_{4}$ after treatment of silymarin. Values are mean \pm SEM.

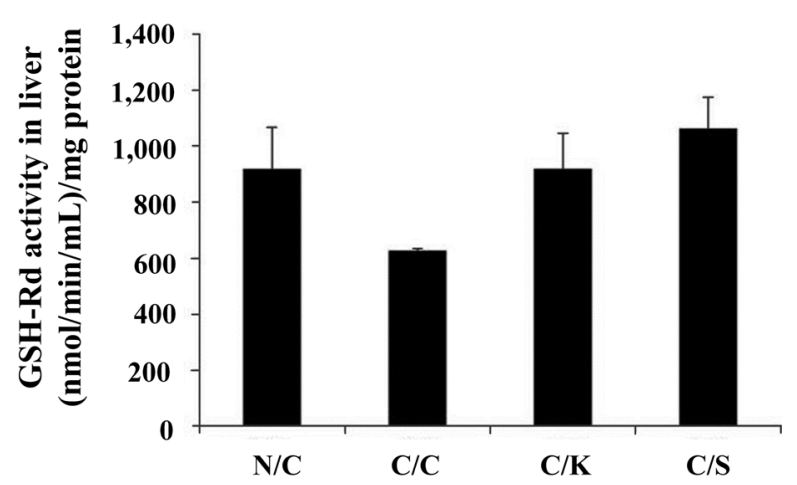

Fig. 4. Glutathione reductase activity in liver. $\mathrm{N} / \mathrm{C}$ : normal mice, $\mathrm{C} / \mathrm{C}$ : $\mathrm{CCl}_{4}$ control, $\mathrm{C} / \mathrm{K}$ : injected with $\mathrm{CCl}_{4}$ after treatment of Halla-Gold kiwi fruits, $\mathrm{C} / \mathrm{S}$ : injected with $\mathrm{CCl}_{4}$ after treatment of silymarin. Values are mean \pm SEM.

\section{Effect of Hall-Gold kiwi fruit extract on 4-HNE and CYP450 2E1 expressions}

4-hydroxynonenal (4-HNE) and CYP450 2E1 expressions in mouse liver homogenates are shown in Figs. 5 and 6. 4HNE, an aldehyde product of lipid peroxidation, is relatively stable and is able to diffuse into the cytosol from the site of production in the membrane [5, 6]. 4-HNE expression in the $\mathrm{CCl}_{4}$ group was significantly increased $(p<0.01)$ compared to that in the control. Pretreatment of kiwi extract significantly prevented up regulation of 4-HNE expression by $\mathrm{CCl}_{4}$ challenge. To investigate the possible mechanisms by which kiwi extract prevented the hepatic injuries induced by $\mathrm{CCl}_{4}$, hepatic CYP2E1 expression was assessed. $\mathrm{CCl}_{4}$ treatment significantly suppressed hepatic CYP2E1 expression, as compared to the control $(p<0.01)$. In contrast, kiwi extract increased $(p<0.05)$ hepatic CYP2E1 expression significantly.

\section{Histopathological examination}

At the microscopic level, liver architecture and hepatocytes of normal mice had no degenerative and lipomatous changes (Fig. 7). In the $\mathrm{CCl}_{4}$-treated group, fatty degenera-

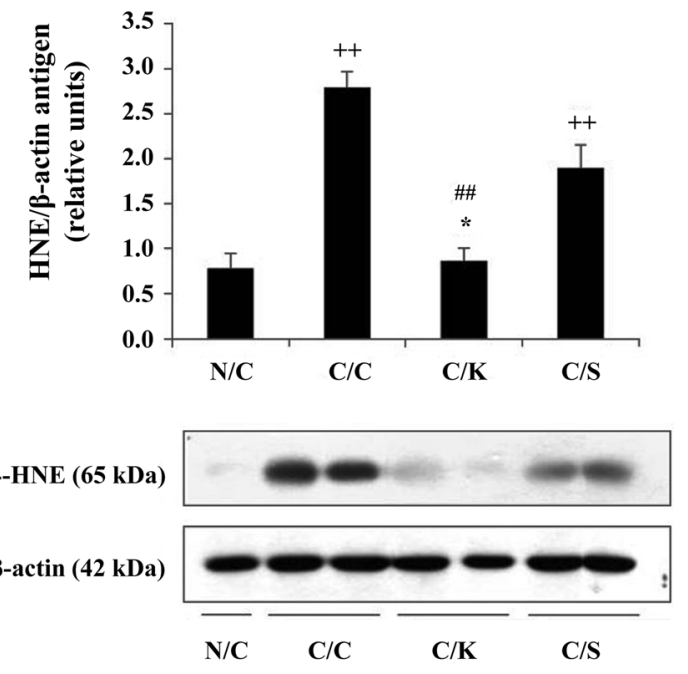

Fig. 5. 4-hydroxynonenal expression in liver. $\mathrm{N} / \mathrm{C}$ : normal mice, $\mathrm{C} / \mathrm{C}$ : $\mathrm{CCl}_{4}$ control, $\mathrm{C} / \mathrm{K}$ : injected with $\mathrm{CCl}_{4}$ after treatment of Halla-Gold kiwi fruits, $\mathrm{C} / \mathrm{S}$ : injected with $\mathrm{CCl}_{4}$ after treatment of silymarin. Values are mean $\pm \mathrm{SEM} .{ }^{++} p<0.01 v s . \mathrm{N} / \mathrm{C}$; ${ }^{* *} p<0.01$ vs. C/C; ${ }^{\#} p<0.01$ vs. C/S.

A

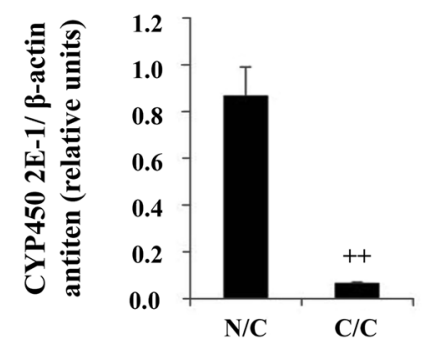

CYP450 2E-1(50 kDa)

$\beta$-actin (42 kDa)

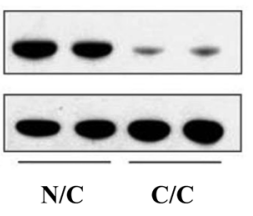

B

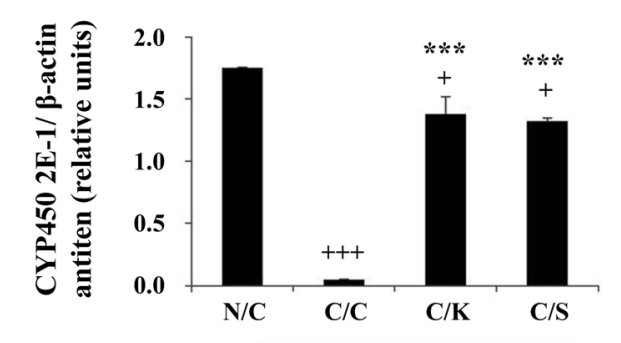

CYP450 2E-1(50 kDa)

$\beta$-actin (42 kDa)

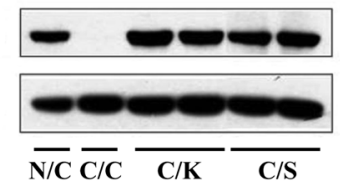

Fig. 6. Cytochrome $4502 \mathrm{E} 1$ expression in liver. (A) Cytochrome 450 $2 \mathrm{E} 1$ expression reduced by $\mathrm{CCl}_{4}$ treatment. (B) Kiwi extract and syrimarin restored Cytochrome450 2E1 expression. N/C: normal mice, $\mathrm{C} / \mathrm{C}$ : $\mathrm{CCl}_{4}$ control, $\mathrm{C} / \mathrm{K}$ : injected with $\mathrm{CCl}_{4}$ after treatment of Halla-Gold kiwi fruits, C/S: injected with $\mathrm{CCl}_{4}$ after treatment of silymarin. Values are mean \pm SEM. ${ }^{+} p<0.05,{ }^{++} p<$ $0.01,{ }^{+++} p<0.001$ vs. N/C; ${ }^{* * * *} p<0.001$ vs. C/C. 

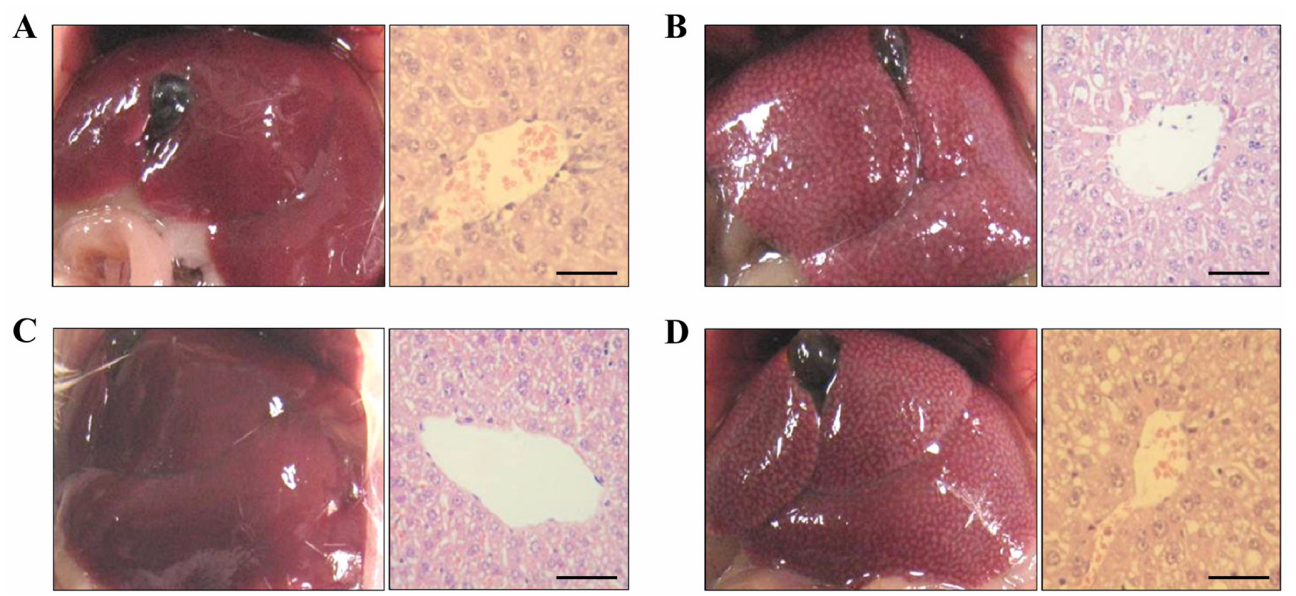

Fig. 7. Histopathology in liver. (A) normal mice, (B) $\mathrm{CCl}_{4}$ control, (C) injected with $\mathrm{CCl}_{4}$ after treatment of Halla-Gold kiwi fruits, (D) injected with $\mathrm{CCl}_{4}$ after treatment of silymarin. Scale bars $=50 \mu \mathrm{m}$.

tion, especially that of hepatocytes, settled in the central zone was clearly identified. In the kiwi extract group, the liver and hepatocytes were in good condition, and were similar to those observed in control animals.

\section{Discussion}

Liver damage induced by $\mathrm{CCl}_{4}$ is a model commonly used to screen for the anti-hepatotoxic/hepatoprotective activity of drugs $[2,3]$. The increased plasma levels of ALT and AST, which are released into the circulation after cellular damage, have been suggested to damage the structural integrity of the liver [19]. In the present study, pretreatment with kiwi extract effectively protected mice against $\mathrm{CCl}_{4}$-induced hepatotoxicity, as evidenced by decreased plasma ALT and AST levels as compared to a positive control. Increased oxidative stress represents an imbalance between the intracellular production of free radicals and cellular defense mechanisms. Especially, lipid peroxidation is one of the most important markers of oxidative stress. Many studies have reported that $\mathrm{CCl}_{4}$ increases hepatic levels of MDA, depletes GSH, and decreases the activities of antioxidant enzymes [12, 18, 28].

The expression of 4-HNE induced by treatment of $\mathrm{CCl}_{4}$ in this study was as a result of the increase of lipid peroxidation. 4-HNE forms covalent cross-links with proteins via lysine, cysteine, and histidine residues [25, 26]. 4-HNE is normally detoxified by conjugation with GSH [11, 22, 27]. In this study, GSH levels were not measured, but the observed increase in the expression of 4-HNE could have been due to a depletion of GSH stores. The GSH system includes antioxidant enzymes such as GSH-px, GSH-rd and glutathioneS-transferase. The determination of these enzymes is appropriate for an assessment of the oxidative stress status in cells, and in $\mathrm{CCl}_{4}$ treated rats, deletion of GSH-px, GSH-rd and GSH has been previously reported [15]. In this study, kiwi extract maintained the activity of GSH-rd and reduced 4HNE expressions. Therefore, one of the protective mecha- nisms of kiwi extract against acute hepatotoxicity could be the restoration of anti-oxidative enzyme activity and prevention of lipid peroxidation.

Biotransformed metabolites of $\mathrm{CCl}_{4}$ formed by cytochrome P450 (CYP) 2E1 include trichloromethyl radical $\left(\mathrm{CCl}_{3}\right)$ and trichloromethyl peroxyl radical $\left(\mathrm{CCl}_{3} \mathrm{O}_{2}\right)$. The role of CYP2E1 in the initiation of $\mathrm{CCl}_{4}$-induced hepatotoxicity has already been reported [29]. By using cyp2e1-/- mice, no hepatotoxicity of $\mathrm{CCl}_{4}$ was observed in the absence of CYP2E1, unlike the significant liver damage observed in the wild type control mice. However, in the present study, the expression of CYP2E1 was dramatically decreased by $\mathrm{CCl}_{4}$ treatment. This result was in agreement with the previous reports [24, 28], in which treatment of mice with $\mathrm{CCl}_{4}$ caused a reduction in levels of CYP2E1 protein and mRNA. After $\mathrm{CCl}_{4}$ is bioactivated, the resulting reactive radical binds covalently to CYP2E1, either at the heme group of CYP or at the active site of the enzyme, causing suicidal inactivation of the CYP pathway $[8,20]$. It suggests that the other potential mechanism of the protective effect of kiwi extract may be mediated through a direct interaction with the reactive metabolite of $\mathrm{CCl}_{4}$, since kiwi extract has novel radical scavenging activity.

Our study demonstrated the anti-oxidative activity of Halla-Gold kiwi extract. Kiwi fruit was previously reported to contain a number of anti-oxidant constituent, such as vitamin $C$ and E, caffeic acid, naringenin, quercetin and epicathechin [9]. Overall, gold kiwi was evaluated to have better anti-oxidative effects than green kiwi, both of which having stronger anti-oxidative effects than other fruits [14], and this was further confirmed in the present study.

Therefore, we proposed the novel role of Halla-Gold kiwi fruit of Jeju Island in South Korea for the effective prevention of hepatotoxicity and further disease caused by excessive oxidation.

\section{Acknowledgments}

This study was carried out with the support of "Coopera- 
tive Research Program for Agricultural Science \& Technology Development (Project No. PJ006686)", Rural Development Administration, Republic of Korea.

\section{References}

1. Bradford MM. A rapid and sensitive method for the quantitation of microgram quantities of protein utilizing the principle of protein-dye binding. Anal Biochem 1976, 72, 248-254.

2. Brattin WJ, Glende EA Jr, Recknagel RO. Pathological mechanisms in carbon tetrachloride hepatotoxicity. J Free Radic Biol Med 1985, 1, 27-38.

3. Brautbar N, Williams J 2nd. Industrial solvents and liver toxicity: risk assessment, risk factors and mechanisms. Int $\mathbf{J}$ Hyg Environ Health 2002, 205, 479-491.

4. Collins BH, Horská A, Hotten PM, Riddoch C, Collins AR. Kiwifruit protects against oxidative DNA damage in human cells and in vitro. Nutr Cancer 2001, 39, 148-153.

5. Esterbauer H, Cheeseman KH, Dianzani MU, Poli G, Slater TF. Separation and characterization of the aldehydic products of lipid peroxidation stimulated by $\mathrm{ADP}-\mathrm{Fe}^{2+}$ in rat liver microsomes. Biochem J 1982, 208, 129-140.

6. Esterbauer H, Schaur RJ, Zollner H. Chemistry and biochemistry of 4-hydroxynonenal, malonaldehyde and related aldehydes. Free Radic Biol Med 1991, 11, 81-128.

7. Fernandes E, Toste SA, Lima JLFC, Reis S. The metabolism of sulindac enhances its scavenging activity against reactive oxygen and nitrogen species. Free Radic Biol Med 2003, 35, 1008-1017.

8. Fernández G, Villarruel MC, de Toranzo EG, Castro JA. Covalent binding of carbon tetrachloride metabolites to the heme moiety of cytochrome P-450 and its degradation products. Res Commun Chem Pathol Pharmacol 1982, 35, 283-290.

9. Fiorentino A, D'Abrosca B, Pacifico S, Mastellone C, Scognamiglio M, Monaco P. Identification and assessment of antioxidant capacity of phytochemicals from kiwi fruits. J Agric Food Chem 2009, 57, 4148-4155.

10. Gonzalez FJ. The molecular biology of cytochrome P450s. Pharmacol Rev 1988, 40, 243-288.

11. Grune T, Siems WG, Zollner H, Esterbauer H. Metabolism of 4-hydroxynonenal, a cytotoxic lipid peroxidation product, in Ehrlich mouse ascites cells at different proliferation stages. Cancer Res 1994, 54, 5231-5235.

12. Hsiao G, Lin YH, Lin CH, Chou DS, Lin WC, Sheu JR. The protective effects of PMC against chronic carbon tetrachloride-induced hepatotoxicity in vivo. Biol Pharm Bull 2001, 24, 1271-1276.

13. Hsu YW, Tsai CF, Chang WH, Ho YC, Chen WK, Lu FJ. Protective effects of Dunaliella salina--a carotenoidsrich alga, against carbon tetrachloride-induced hepatotoxicity in mice. Food Chem Toxicol 2008, 46, 3311-3317.

14. Iwasawa H, Morita E, Yui S, Yamazaki M. Anti-oxidant effects of kiwi fruit in vitro and in vivo. Biol Pharm Bull 2011, 34, 128-134.

15. Khan MR, Siddique F. Antioxidant effects of Citharexylum spinosum in $\mathrm{CCl}_{4}$ induced nephrotoxicity in rat. Exp Toxicol Pathol 2012, 64, 349-355.

16. Lee KJ, Choi JH, Jeong HG. Hepatoprotective and antioxidant effects of the coffee diterpenes kahweol and cafestol on carbon tetrachloride-induced liver damage in mice. Food Chem Toxicol 2007, 45, 2118-2125.

17. Motohashi N, Shirataki Y, Kawase M, Tani S, Sakagami H, Satoh K, Kurihara T, Nakashima H, Mucsi I, Varga A, Molnár J. Cancer prevention and therapy with kiwifruit in Chinese folklore medicine: a study of kiwifruit extracts. J Ethnopharmacol 2002, 81, 357-364.

18. Quan J, Piao L, Xu H, Li T, Yin X. Protective effect of iridoid glucosides from Boschniakia rossica on acute liver injury induced by carbon tetrachloride in rats. Biosci Biotechnol Biochem 2009, 73, 849-854.

19. Recknagel RO, Glende EA Jr, Dolak JA, Waller RL. Mechanisms of carbon tetrachloride toxicity. Pharmacol Ther 1989, 43, 139-154.

20. Roberts BJ, Song BJ, Soh Y, Park SS, Shoaf SE. Ethanol induces CYP2E1 by protein stabilization. Role of ubiquitin conjugation in the rapid degradation of CYP2E1. J Biol Chem 1995, 270, 29632-29635.

21. Rudnicki M, Silveira MM, Pereira TV, Oliveira MR, Reginatto FH, Dal-Pizzol F, Moreira JC. Protective effects of Passiflora alata extract pretreatment on carbon tetrachloride induced oxidative damage in rats. Food Chem Toxicol 2007, 45, 656-661.

22. Spitz DR, Malcolm RR, Roberts RJ. Cytotoxicity and metabolism of 4-hydroxy-2-nonenal and 2-nonenal in $\mathrm{H}_{2} \mathrm{O}_{2}^{-}$ resistant cell lines. Do aldehydic by-products of lipid peroxidation contribute to oxidative stress? Biochem J 1990, 267, 453-459.

23. Taira Z, Yabe K, Hamaguchi Y, Hirayama K, Kishimoto M, Ishida S, Ueda Y. Effects of Sho-saiko-to extract and its components, Baicalin, baicalein, glycyrrhizin and glycyrrhetic acid, on pharmacokinetic behavior of salicylamide in carbon tetrachloride intoxicated rats. Food Chem Toxicol 2004, 42, 803-807.

24. Tierney DJ, Haas AL, Koop DR. Degradation of cytochrome P450 2E1: selective loss after labilization of the enzyme. Arch Biochem Biophys 1992, 293, 9-16.

25. Uchida K, Stadtman ER. Covalent attachment of 4hydroxynonenal to glyceraldehyde-3-phosphate dehydrogenase. A possible involvement of intra- and intermolecular crosslinking reaction. J Biol Chem 1993, 268, 6388-6393.

26. Uchida K, Toyokuni S, Nishikawa K, Kawakishi S, Oda H, Hiai H, Stadtman ER. Michael addition-type 4hydroxy-2-nonenal adducts in modified low-density lipoproteins: markers for atherosclerosis. Biochemistry 1994, 33, $12487-$ 12494.

27. Ullrich O, Grune T, Henke W, Esterbauer H, Siems WG. Identification of metabolic pathways of the lipid peroxidation product 4-hydroxynonenal by mitochondria isolated from rat kidney cortex. FEBS Lett 1994, 352, 84-86.

28. Weerachayaphorn J, Chuncharunee A, Jariyawat S, Lewchalermwong B, Amonpatumrat S, Suksamrarn A, Piyachaturawat $\mathbf{P}$. Protection of centrilobular necrosis by Curcuma comosa Roxb. in carbon tetrachloride-induced mice liver injury. J Ethnopharmacol 2010, 129, 254-260.

29. Wong FWY, Chan WY, Lee SST. Resistance to carbon tetrachloride-induced hepatotoxicity in mice which lack CYP2E1 expression. Toxicol Appl Pharmacol 1998, 153, 109-118. 